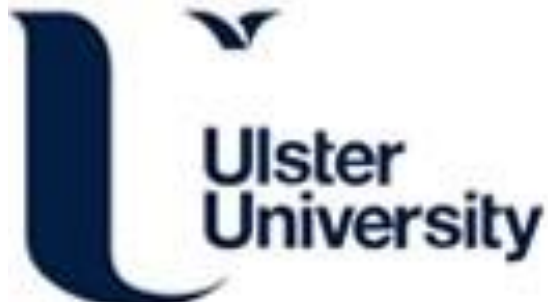

\section{Circuit Warz, the Games; Collaborative and Competitive Game-based Learning in Virtual Worlds}

Callaghan, MJ., McCusker, K., Losada, J., Harkin, JG., \& Wilson, S. (2012). Circuit Warz, the Games;

Collaborative and Competitive Game-based Learning in Virtual Worlds. In Unknown Host Publication (pp. 7579). 9th International Conference on Remote Engineering and Virtual Instrumentation REV 2012. https://doi.org/10.1109/REV.2012.6293095

Link to publication record in Ulster University Research Portal

\section{Published in:}

Unknown Host Publication

Publication Status:

Published (in print/issue): 06/07/2012

DOI:

10.1109/REV.2012.6293095

\section{Document Version}

Publisher's PDF, also known as Version of record

\section{General rights}

Copyright for the publications made accessible via Ulster University's Research Portal is retained by the author(s) and / or other copyright owners and it is a condition of accessing these publications that users recognise and abide by the legal requirements associated with these rights.

\section{Take down policy}

The Research Portal is Ulster University's institutional repository that provides access to Ulster's research outputs. Every effort has been made to ensure that content in the Research Portal does not infringe any person's rights, or applicable UK laws. If you discover content in the Research Portal that you believe breaches copyright or violates any law, please contact pure-support@ulster.ac.uk. 


\title{
Circuit Warz, the Games; Collaborative and Competitive Game-based Learning in Virtual Worlds
}

\author{
MJ.Callaghan, K.McCusker, J. Lopez Losada, JG.Harkin \& S.Wilson \\ Intelligent Systems Research Center \\ University of Ulster, Derry \\ Northern Ireland, UK \\ mj.callaghan@ulster.ac.uk
}

\begin{abstract}
In recent years there has been significant growth in the use of video games technologies and game mechanics for teaching and learning. These environments and techniques offer the ability to create complex, highly interactive simulations with solid theoretical underpinnings to present teaching material in new and highly interactive ways. This paper discusses and practically demonstrates how video games mechanics can be used to create highly immersive and engaging user experiences to teach engineering related material. Circuit Warz; The Games, project is introduced and demonstrates how a game-based approach, using a collaborative team-based competitive format, can be used to create immersive, highly engaging student learning experiences.
\end{abstract}

Keywords; Virtual worlds, engineering education, virtual learning environments, game based learning

\section{INTRODUCTION}

Gamification is a term used to describe the application of video game mechanics to non-game processes in order to improve user engagement. This type of game based learning is increasingly been used in educational settings and is widely predicted to become mainstream in the next 3-5 years [1-6]. This paper discusses the practicalities of using game mechanics for educational and teaching purposes in the context of electrical and electronic engineering. It will show how virtual world platforms e.g. Opensim could be used to rapidly prototype simulations to teach advanced electronic/electrical circuit theory, through a game based learning experience in a 3D immersive world, where teams of students work together collaboratively and competitively to bias electronic circuits.

Section 2 of the paper discusses recent University of Ulster research in virtual worlds and video games and provides a practical overview of the implementation of a game based approach to teaching. Section 3 concludes the paper.

\section{GAME BASED LEARNING IN VIRTUAL WORLD'S}

Internet-based 3D virtual worlds are immersive environments which facilitate an advanced level of social networking where residents can explore and socialize by participating in individual and group activities [7+8]. The Serious Games \& Virtual Worlds research team at the Intelligent Systems Research Center (ISRC), University of Ulster focus on the potential of virtual worlds and video games technologies for undergraduate/postgraduate teaching of electrical and electronic engineering related subjects [9].

In this context "Circuit Warz, The Games" project was conceived with the overall objective to investigate if creating a compelling, engaging, immersive team based game, which facilitates collaborative/competitive group interactions to teach electrical and electronic theory and principles would increase student engagement. The project was created using the Opensim virtual world platform, integrated with the Moodle virtual learning environment and SLOODLE [10].

Circuit Warz, The Games is a team based exercise where groups of students work together collaboratively and compete competitively against other teams to complete a virtual assault course, which is in practice a series of electronic and electrical circuits (puzzles) which need to be solved (i.e. biased correctly) in order to complete the game and progress to the next level. The game is designed so that students can apply the theory learned in class practically. Students have to work together collaboratively to make strategic decisions under strict time constraints to win the game e.g. students can solve circuits/puzzles by using a "rule of thumb" approach to make informed guesses related to finding the correct answer to complete each stage or can decide to spend more time working out the correct and more accurate values needed to bias the circuit. The more time taken to complete the game means less points acquired where the team with the most points win. To aid in the decision making process the game design and implementation uses the advanced presentation capabilities of the virtual world platform to allow the students to visualize electrical/electronic phenomena in new ways to reinforce understanding e.g. relative voltage drops across circuit components. The virtual assault course is made up of five stages of increasing more complex electronic and electrical circuits which need to be correctly biased/solved to proceed. The stages currently implemented include a series/parallel resistor circuit (Fig.1), R/C filter circuit (Fig.2), Graetz bridge (Fig.3), Wheatstone bridge (Fig.4), and a weighted summing amplifier circuit (Fig.5).

The final paper will expand on and discuss the complete architecture, implementation and evaluation process of the system described in detail and will also examine the shortcomings of current approaches to implementation in this area and how these can be overcome. 


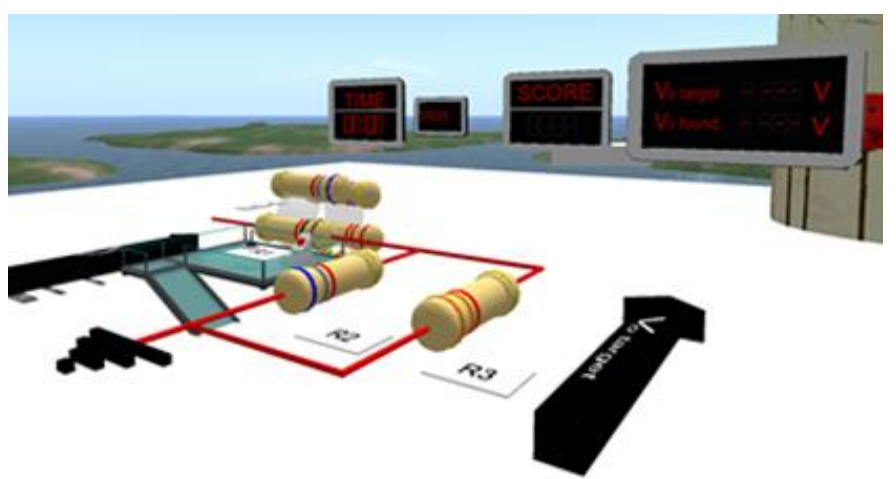

Figure 1 Series/parallel resistor circuit

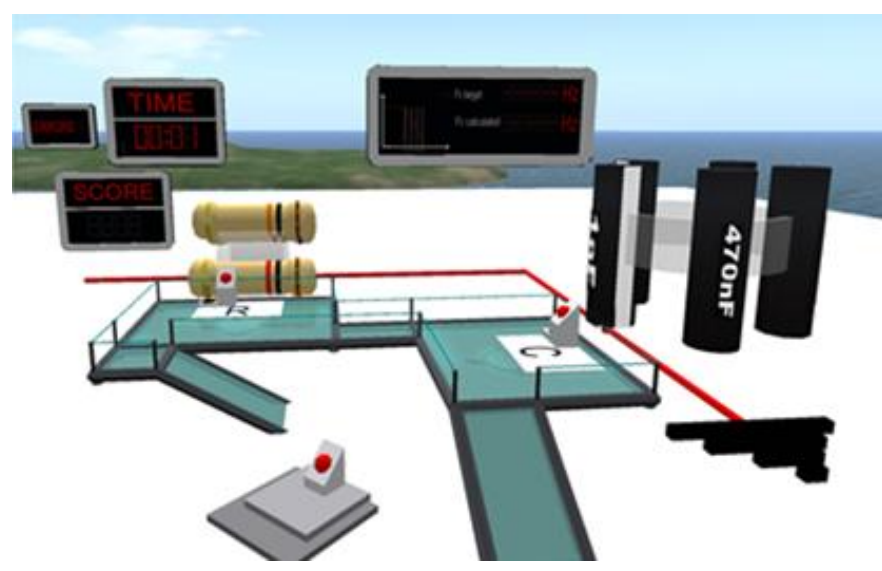

Figure 2 R/C Filter Circuit

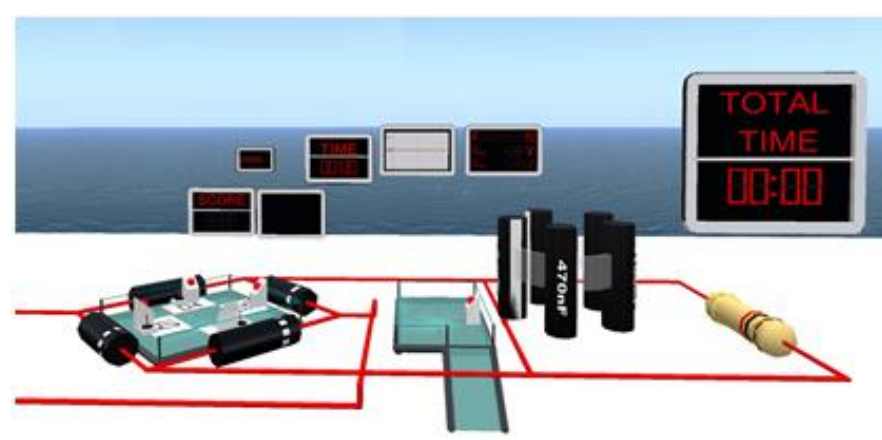

Figure 3 Graetz Bridge

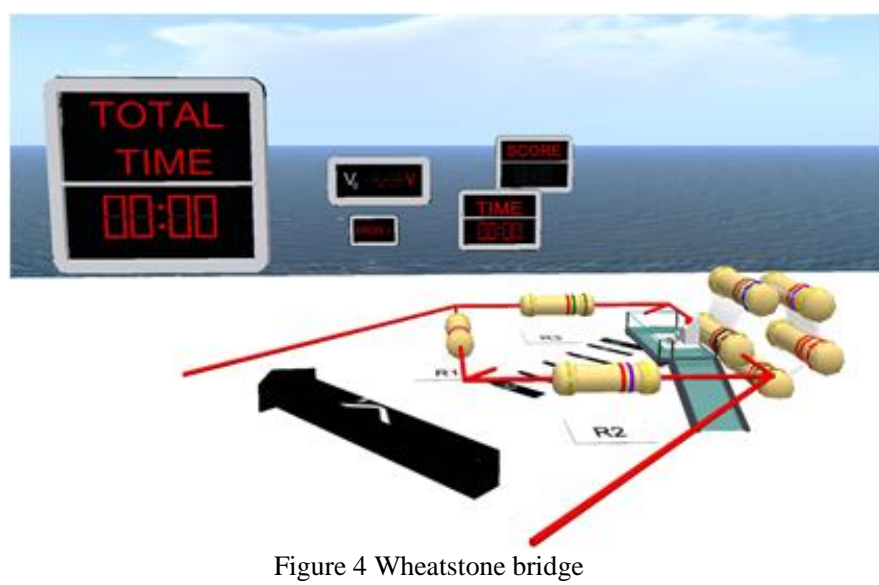

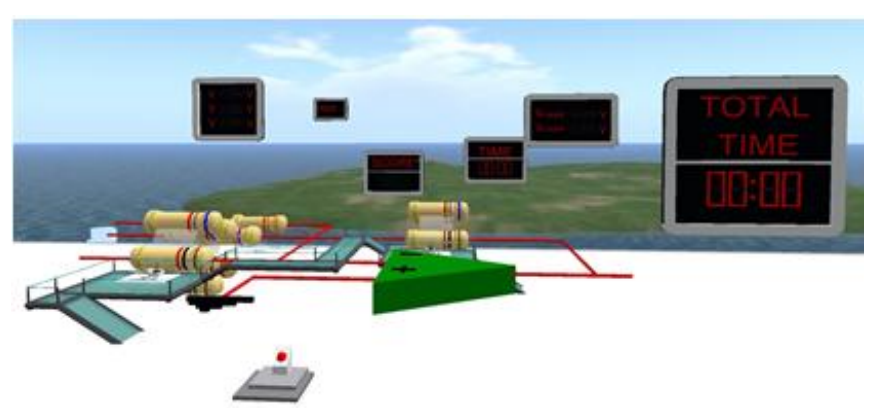

Figure 5 Weighted Summing Amplifier Circuit

\section{CONCLUSION}

This paper provided an overview on ongoing research at the Intelligent Systems Research Center, University of Ulster, Northern Ireland into the use of virtual worlds and virtual learning environments for teaching. The Circuit Warz project was introduced and a number of complex, highly interactive and engaging simulations described which make effective use of game play mechanics to engage students. This approach potentially offers a new engaging and highly interactive way to teach engineering related material

\section{REFERENCES}

[1] Second Life. Last accessed 03/2010 From: http://www.secondlife.com [2] Kirriemuir, J. (2007) An update of the July 2007 'snapshot' of UK higher and further education developments in Second Life Eduserv Foundation, Bath [3] Kemp, J. and Livingstone, D. (2006) Putting a Second Life 'Metaverse' skin on learning management systems. SLCC Workshop San Francisco

[4] Chang, Y., Aziz, E.-S., Esche, S. K. \& Chassapis, C. (2012). Game-based laboratory for gear design. Computers in Education Journal, Vol. 22, No. 1.

[5] Aziz, E.-S., Esche, S. K. \& Chassapis, C. (2010). Review of the state of the art in virtual learning environments based on multi-player computer games. Computers in Education Journal, Vol. 20, No. 1, pp. 22-35.

[6] Aziz, E.-S., Esche, S. K. \& Chassapis, C. (2009). Content-rich, interactive online laboratory systems. Computer Applications in Engineering Education Journal, Vol. 17, No. 1, pp. 61-79.

[7] Kirriemuir, J. (2007) An update of the July 2007 'snapshot' of UK higher and further education developments in Second Life Eduserv Foundation Bath [8] Kemp, J. and Livingstone, D. (2006) Putting a Second Life 'Metaverse' skin on learning management systems. Paper presented at the Second Life Education Workshop at SLCC San Francisco

[9] Callaghan MJ, Harkin J, Scibilia G, Sanfilippo F, McCusker K, Wilson S, (Jun 2008) "Experiential based learning in 3D Virtual Worlds", Proceedings of Remote Engineering and Virtual Instrumentation (REV 2008) Conference, Dusseldorf, Germany, June 2008

[10] MJ.Callaghan, K.McCusker, J.Losada, JG.Harkin and S.Wilson (November 2009). "Engineering Education Island: Teaching Engineering in Virtual Worlds". ITALICS (Innovation in Teaching And Learning in Information and Computer Sciences), Vol. 8 Issue 3 November 2009

\section{AUTHORS}

Michael Callaghan is a Senior Lecturer at the University of Ulster, Northern Ireland and leads the activities of the Serious Games and Virtual Worlds research team at the Intelligent Systems Research Center. Kerri McCusker and Julio Lopez Losada are research associates in virtual worlds at the Intelligent Systems Research Center, University of Ulster. Dr Jim Harkin and Dr Shane Wilson are Lecturers at the University of Ulster and are both members of the Intelligent Systems Research Center. 